\title{
Tantangan Agama di Era Globalisasi: Analisis Strategi Komunikasi, Karakteristik dan Materi Dakwah
}

\author{
Bara Izzat Wiwah Handaru \\ Mahasiswa, Sekolah Pascasarjana, UIN Syarif Hidayatullah Jakarta, Indonesia \\ Wakil Rektor I, STT Baptis Kalvari Jakarta, Indonesia \\ email: izzatbara@gmail.com
}

\begin{abstract}
The revolution in technology and communication media in this era of globalization has made the phenomenon of Islamic da'wah experience significant progress globally. This can be seen when the da'wah style has used advances in information technology so that the da'wah message is more widespread that is able to touch international aspects. But in reality, this change in pattern gave birth to new problems in the world of da'wah. This article tries to answer the main problems formulated in the major questions, namely; What are the challenges of religion in the era of globalization, using an analysis of communication strategies, characteristics and material for da'wah? According to Gill Branston and Roy Stafford (2010), there are several points explained about globalization. First, approaches to globalized media. Explain how to approach da'wah in the use of global media. Second, global-local flows. Explain how far the development of the flow of da'wah ideas that have reached the global world. Third, global futures? Explain how changes will occur in the world of da'wah in the future global era. In the end, the research provides insight into the topic of the problem in this paper. First, practically the da'wah movement in information technology and media in the era of globalization is based on Islam rahmatan lil 'alamin. Even though on the other hand, the impact of the globalization process related to religious life is the increasingly diminishing space for human religiosity itself. Second, the orientation in spreading da'wah globally is ukhuwah basyariyah which always fosters brotherhood among human beings. The attitude of humanism regardless of religious background, skin color and race. Third, have hope in the waiting period for the day to come (Al-Muntazhar). A principle that gives good news about a bright future and the implementation of all social justice for all mankind.
\end{abstract}

\section{Keywords:}

Religious Challenges, Globalization Era, Communication Strategies, Da'wah Content 


\begin{abstract}
Abstrak
Revolusi dalam bidang teknologi dan media komunikasi di era globalisasi ini membuat fenomena dakwah Islam mengalami kemajuan yang signifikan secara global. Hal ini dapat dilihat ketika corak dakwah sudah menggunakan kemajuan teknologi informasi agar pesan dakwah lebih meluas yang mampu menyentuh aspekaspek internasional. Namun pada kenyataannya, perubahan pola ini melahirkan permasalahan baru dalam dunia dakwah. Artikel ini mencoba menjawab permasalahan utama yang dirumuskan dalam pertanyaan mayor, yaitu; bagaimana tantangan agama di era globalisasi, dengan menggunakan analisis strategi komunikasi, karakteristik dan materi dakwah? Menurut Gill Branston dan Roy Stafford (2010), ada beberapa point yang dijelaskan mengenai globalisasi. Pertama, approaches to globalised media. Menjelaskan bagaimana pendekatan dakwah dalam penggunaan media global. Kedua, global-local flflows. Menjelaskan sejauh mana perkembangan pengaliran ide dakwah yang sudah mencapai dunia global. Ketiga, global futures? Menjelaskan bagaimana perubahan yang akan terjadi dalam dunia dakwah di era global masa depan. Pada akhirnya, penelitian memberikan pandangan terhadap topik permasalahan dalam makalah ini. Pertama, secara praktis pergerakan dakwah dalam teknologi dan media informasi di era globalisasi di dasari oleh Islam rahmatan lil 'alamin. Sekalipun disisi lain dampak proses globalisasi yang terkait dengan kehidupan keagamaan adalah makin menepisnya ruang religiusitas manusia itu sendiri. Kedua, orientasi dalam penyebaran dakwah secara global adalah ukhuwah basyariyah yang selalu membina persaudaraan sesama manusia. Sikap humanisme tanpa memandang latar belakang agama, warna kulit dan ras masyarakat. Ketiga, memiliki pengharapan dalam masa penantian akan hari yang akan datang (Al-Muntazhar). Sebuah prinsip yang memberikan kabar gembira tentang masa depan yang gemilang dan pelaksanaan segenap keadilan sosial bagi seluruh umat manusia.
\end{abstract}

\title{
Kata Kunci:
}

Tantangan Agama, Era Globalisasi, Strategi Komunikasi, Materi Dakwah

\section{Pendahuluan}

Pada prinsipnya, Islam merupakan agama yang diturunkan Allah kepada Nabi Muhammad SAW, untuk membina umat manusia supaya berpegang teguh kepada ajaranajaran yang benar serta untuk mencapai kebahagiaan hidup manusia, baik dunia masa kini maupun akhirat. Agama Islam merupakan agama penyempurna dari keberadaan agama- 
Tantangan Agama di Era Globalisasi: Analisis Strategi Komunikasi, Karakteristik dan Materi Dakwah

agama sebelumnya. Perkembangan agama Islam yang disebarkan oleh Nabi Muhammad SAW di Makkah, Madinah dan kemudian berkembang keseluruh dunia tidak lain adalah karena adanya proses dakwah yang dilakukan oleh tokoh Islam. Perkembangan dakwah Islamiyah inilah yang menyebabkan agama Islam senantiasa berkembang dan disebarluaskan kepada kehidupan manusia. ${ }^{1}$

Dan seiring perkembangan di era globalisasi ini membuat cara berdakwah pun ikut mengalami perkembangan yang signifikan. Dakwah tidak lagi dilakukan secara sederhana, tetapi mulai memanfaatkan kemajuan teknologi informasi agar pesan dakwah lebih meluas dan bisa dilakukan secara efektif. Kalangan yang dijangkau bisa menjadi lebih luas dan begitu pula dampak yang ditimbulkannya. Dakwah tidak hanya dilakukan sebatas pemberian khutbah di Masjid atau Mushalla, kantor-kantor, sekolah dan lembaga formal lainnya. Tetapi seiring dengan meningkatnya kemajuan teknologi informasi penyebaran dakwah Islamiyah bisa dilakukan melalui media teknologi, seperti media televisi, radio, media cetak maupun internet (facebook). Untuk mencapai dakwah yang efektif, maka diperlukan media. Merebaknya media saat ini seperti media cetak dan online merupakan salah satu wujud dari era reformasi dan keterbukaan informasi. Fungsi media itu sendiri adalah memberikan informasi, pendidikan, hiburan, dan kontrol sosial. ${ }^{2}$

Secara historis, perkembangan globalisasi seakan tidak bisa dibendung lajunya memasuki setiap sudut negara dan menjadi sebuah keniscayaan. Era ini menghendaki setiap negara beserta individunya harus mampu bersaing satu sama lain baik antar negara maupun antar individu. Pengaruh yang ada dari globalisasi pada aspek kehidupan meskipun awal tujuannya diarahkan pada bidang ekonomi, namun akhirnya berdampak juga kepada bidang agama dan budaya juga, dan ini memberikan dampak multidimensi. ${ }^{3}$ Hal ini tentunya akan membawa pengaruh yang sangat signifikan terhadap orientasi dakwah. Untuk mendukung hal tersebut kajian-kajian syariat perlu disejajarkan dengan kajian-kajian non syariat yang merujuk kapada perkembangan ilmu pengetahuan dan teknologi, karena perkembangan teknologi terutama perkembangan teknologi komunikasi tidak hanya mempengaruhi satu

1 Sayyid Muhammad Alwi Al-Maliki Al-Hasani. Kiat Sukses Dalam Berdakwah, (Jakarta: Amzah, 2006), xi.

2 Ahmad Y. Samantho, Jurnalistik Islam, (Jakarta: Harakah, 2002), 64.

3 Ratnah Umar, Metode Dakwah Di Era Globalisasi, (Al-Tajdid, Vol. I No.2 /Maret) 
bidang kehidupan masyarakat melainkan hampir mempengaruhi seluruh bidang kehidupan. Oleh sebab itu, selain memanfaatkan perkembangan teknologi itu sendiri dakwah juga diharapkan sebagai penyeimbang terhadap akibat dari perkembangan teknologi itu sendiri. Keragaman hidup duniawi, serbuan berbagai nilai yang bersifat hedonisme dan konsumerisme dakwah dapat memberikan arahan dan bimbingan agar umat tidak mengalami disorientasi dalam rumah peradaban dunia yang penuh dinamika. ${ }^{4}$

Namun pada kenyataannya, perubahan pola ini melahirkan permasalahan baru dan menghadapi berbagai kendala dan tantangan dalam dunia dakwah. Realitas dakwah Islam menjadi problem keagamaan yang krusial dan terkadang dilematis. Terlebih lagi, bila di amati dakwah Islam di era teknologi dan informasi seperti sekarang ini, maka tantangan dan kendalanya akan semakin kompleks. Setidaknya tantangan dakwah Islam tersebut berkaitan dengan ekses globalisasi dan kenyataan pluralitas agama. ${ }^{5}$ Misalnya, menjamurnya ustadz medsos yang berdakwah hanya bermodalkan popularitas, pudarnya prinsip iman Islam dikarenakan sumber dakwah yang plural, dan terjadinya degradasi iman dengan bercampuraduknya nilai-nilai spritual dan nilai-nilai materialisme.

Dari kemajuan teknologi informasi di era globalisasi, asas manfaat dari tujuan yang akan dicapai oleh kegiatan dakwah sejatinya adalah berita tentang pengharapan akan kepastian kehidupan manusia di masa depan. Dakwah seharusnya menyebarkan ajaran agar manusia mematuhi ajaran Allah SWT dan Rasul-Nya dalam kehidupan sehari-hari sehingga tercipta makhluk yang berakhlak mulia, dan tercapainya individu yang baik, keluarga yang sakinah atau harmonis, komunitas yang tangguh serta masyarakat madani yang pada akhirnya akan membentuk bangsa yang sejahtera dan maju. ${ }^{6}$ Berdasarkan dari pengertian globalisasi yang menjelaskan sebuah fenomena bahwa zaman sekarang informasi dapat diperoleh dengan mudah melalui media massa, seperti radio, televisi, surat kabar dan internet. Dalam buku Melawan Globalisasi; Reinterpretasi Ajaran Islam, karangan A.Qodry Azizy seperti yang dikutip dari Akbar S Ahmed dan Hansting Donnan menyebutkan globalisasi adalah perkembangan-pekembangan yang cepat didalam teknologi komunikasi,

4 A. Qodri Azizy, Melawan Globalisasi, (Yogyakarta: Pustaka Pelajar, 2004), .

5 A. Qodri Azizy, Melawan Globalisasi; Reinterpretasi Ajaran Islam, (Yogyakarta: Pustaka pelajar, 2004), 74.

6 Wahidin Saputra, Pengantar Ilmu Dakwah, (Jakarta: PT. Rajagrafindo Persada, 2011), 9. 
informasi yang bisa membawa bagian-bagian dunia yang jauh menjadi hal-hal yang bisa dijangkau dengan mudah. ${ }^{7}$

Namun pada kenyataan nya ada beberapa dampak negatif globalisasi yang digulirkan oleh dunia Barat yang rawan mempengaruhi kehidupan seorang muslim, dan sekaligus menjadi tantangan dakwah di era globalisasi, yaitu: Pertama, adalah kecenderungan maddiyyah (materialisme) yang selalu kuat pada zaman sekarang ini. Kehidupan kolektif, kebersamaan, gotong royong, telah diganti dengan semangat individualisme yang kuat. Kedua, adanya oknum yang menggunakan media global untuk menyebarkan ajaran paham radikalisme, intoleran, dan berita hoax yang dapat menggangu kenyamanan masyarakat. Ketiga, sekulerisme yang senantiasa memisahkan kehidupan agama dengan urusan masyarakat, karena agama dinilai hanya persoalan privat antar individu semata. Keempat, munculnya relativitas norma-norma etika, moral, dan akhlak. Sehingga dalam suatu konteks masyarakat yang dianggap tabu bisa saja dalam konteks masyarakat yang lain dianggap boleh untuk dilakukan. ${ }^{8}$ Sehingga tidak salah jika Ali Syari'ati berpendapat sebagaimana yang dikutip oleh Ari Ginanjar Agustian mengatakan bahwa bahaya yang paling besar yang dihadapi oleh umat manuysia zaman sekarang ini bukanlah ledakan bom atom, tetapi perubahan fitrah. Unsur kemanusiaan dalam dirinya sedang mengalami kehancuran sedemikian cepat, inilah mesin-mesin berbentuk manusia yang tidak sesuai dengan kehendak Tuhan dan kehendak alam yang fitrah. ${ }^{9}$

Dengan demikian, menurut penulis perlu diadakan kajian yang bersifat komprehensif tentang makna globalisasi, sejarah globalisasi, bentuk-bentuk globalisasi, serta sampai di mana besarnya pengaruh globalisasi terhadap agama Islam khususnya dalam dunia dakwah. Era globalisasi ini merupakan tantangan dalam dunia dakwah dan mau atau tidak semua insan manusia akan mengalaminya. Tentunya pasti akan ada rintangan-rintangan serta hambatan yang harus dihadapi, karena tidak semua kemajuan yang ada di era globalisasi ini diterima oleh ajaran Islam. Maka dari itu, dibutuhkan langkah-langkah yang konkrit dan sistematik untuk menganalisis strategi komunikasi dan tantangan dakwah di era globalisasi

7 WahA. Qodri Azizy, Melawan Globalisasi; Reinterpretasi Ajaran Islam, (Yogyakarta: Pustaka pelajar,2004), 74.

8 Amin Rais,Tauhid Sosial, (Bandung: Mizan, 1998), 65-66.

9 Agustian, Ari Ginanjar. ESQ; Emotional Spiritual Quetiont. Cet. VI; (Jakarta: Arga, 2002), xxi. 
ini. Sehingga dapat dijadikan sebagai acuan pola dakwah yang diharapkan mampu mengembalikan manusia kepada maksud dan tujuan ia diciptakan, dengan memanfaatkan kemajuan dunia globalisasi.

\section{Landasan Teori}

Branston dan Stafford berpendapat bahwa globalisasi hadir dari empat faktor kausalitas-interaksionis. Kelahiran dan penyebutan globalisasi' atas dasar empat aktifitas, diantaranya: pertama, mengambil tempat dalam suatu hal dalam arena global (bukan nasional maupun regional); kedua, kesengajaan dalam penyelenggaraan berbasis skala global; ketiga, pelibatan hubungan saling ketergantungan, sehingga beberapa kegiatan lokal di belahan dunia dibentuk oleh satu sama lain; dan keempat, sering melibatkan teknologi yang memungkinkan produk instan, berupa komunikasi. ${ }^{10}$ Branston dan Stafford mengungkapkan bahwa kepentingan global yang diusung dalam gerakan sosial apapun, termasuk Islam Berkemajuan hendaknya mengindahkan sensitivitas untuk merangkul "perbedaan" dan menekankan cara-cara tertentu yang membuat perbedaan dapat diterima di seluruh kelompok. ${ }^{11}$ Branston dan Stafford berpendapat bahwa globalisasi hadir dari empat faktor kausalitas-interaksionis. Kelahiran dan penyebutan ,globalisasi` atas dasar empat aktifitas, diantaranya: pertama, mengambil tempat dalam suatu hal dalam arena global (bukan nasional maupun regional); kedua, kesengajaan dalam penyelenggaraan berbasis skala global; ketiga, pelibatan hubungan saling ketergantungan,

Secara aplikatif, kajian ini sepenuhnya menerapkan perspektif teori globalisasi dalam studi media, dan beberapa teori yang relevan lainnya. Perspektif teori globalisasi ini kemudian melahirkan berbagai perspektif dan pendekatan, seperti pendekatan imperialisme budaya, homogenisasi, oligopoli, dan beberapa perdebatan yang pada gilirannya melahirkan beberapa konsekuensi kecenderungan sesuai dengan arah pendekatannya. ${ }^{12}$ Perspektif teori globalisasi menunjukkan, bahwa globalisasi adalah khas modern, ia tumbuh dari ekspansi perdagangan di akhir Abad Pertengahan dan diikuti oleh pertumbuhan imperialis dan 404-405.

10 Gill Branston dan Roy Stafford, The Media Student's Book, edisi ketiga (London : Routledge, 2003),

11 Gill Branston \& Roy Stafford, The Media Student's Book, 143.

12 Gill Branston \& Roy Stafford, The Media Student's Book, 404. 
kemudian pasca-imperialis Barat atas seluruh dunia. Globalisasi dikatakan terjadi ketika aktifitas berlangsung di arena global; dan sengaja diselenggarakan pada skala global; melibatkan banyak saling ketergantungan, sehingga kegiatan lokal di berbagai belahan dunia dibentuk oleh satu sama lain; dan sering melibatkan teknologi yang memungkinkan sesuatu menjadi lebih cepat, baik dalam berhubungan maupun berkomunikasi. ${ }^{13}$

Beberapa pengamat menilai, bahwa terjadinya globalisasi beserta karakteristik yang menyertainya telah menunjukkan adanya proses homogenisasi, yang mengarah ke 'McWorld'. Pengamat yang lain menilai, bahwa karakteristik 'lokal' bertahan, kadang-kadang dalam bentuk loyalitas agama atau etnis budaya terbelakang; kadang-kadang dalam bentuk makananmanakan lokal, kostum, adat istiadat dan latarbelakang sejarah. ${ }^{14}$ Sejak awal penyebarannya, perusahaan media global telah terkait erat dengan sejarah imperialis. Terdapat bukti yang cukup signifikan di mana sebagian besar berita, informasi dan hiburan dari negara-negara Barat utama yang dipimpin oleh Amerika Serikat di sampaikan melalui satu arah ke seluruh dunia. Secara signifikan, arus regional seringkali tergantung pada penyebaran bahasa global. ${ }^{15}$

Teori media dengan cara yang sepenuhnya politik dapat menunjukkan bukti ini. Melalui pendekatan ekonomi politik, Herbert Schiller- sebagaimana dikutip oleh Branston mengungkapkan, banyak dari globalisasi komunikasi telah di dorong sejak Perang Dunia Kedua untuk kepentingan komersial dari perusahaan besar yang berbasis di AS. Hal ini bukan lompatan raksasa untuk menyatakan bahwa kekuatan media AS adalah bentuk imperialisme budaya ${ }^{27}$. Herbert Schiller juga berpendapat, dominasi iklan media komersil AS tidak hanya menjadikan model AS popular di seluruh dunia, namun juga telah mendorong dan menanamkan budaya konsumerisme untuk satu keinginan menjadi gaya Amerika. Budaya tradisional akan hancur dalam proses ini, dan bentuk-bentuk baru dari ketergantungan budaya akan terbentuk dan mencerminkan hubungan dengan kekuasaan imperialis. ${ }^{16}$

13 Gill Branston \& Roy Stafford, The Media Student's Book , 404-405.

14 Gill Branston \& Roy Stafford, The Media Student's Book, 406

15 Gill Branston \& Roy Stafford, The Media Student's Book, 408.

16 Gill Branston \& Roy Stafford, The Media Student's Book, 408. 
Mari kita kembali ke perdebatan yang telah dijelaskan sebelumnya. Pertama, pertanyaan lain telah diajukan dari model imperialisme media yang penekanan kepemilikan bisa menyiratkan apa yang diinginkan pada setiap televisi di AS. Misalnya, mau tidak mau mengungkapkan hanya nilai konsumtif, baik dalam program itu sendiri, maupun melalui iklan yang membiayainya. Ini mengabaikan keanekaragaman gambar, tema dan informasi yang bisa dan memang harus muncul pada pembiayaan televisi komersil. ${ }^{17}$ Kedua, adakalanya yang terjadi bahwa kekuatan proses global yang terpusat seperti Branding dapat bekerja melawan kepentingan pemiliknya. Merek global olahraga, seperti Kacang Olimpiade tidak hanya publisitas untuk Nike dan lain-lain, tetapi secara bersamaan menjadi 'profil berita besar' tentang eksploitasi pekerja anak di Indonesia, Pakistan, dan lain-lain oleh perusahaan yang sama. ${ }^{18}$ Ketiga, model imperialisme media dapat menyiratkan bahwa penonton pasti menjadi, atau ingin menjadi konsumen hanya sebagai akibat menonton program tersebut. Namun beberapa hasil penelitian menunjukkan situasi yang lebih kompleks. Roger Silverstone menunjukkan bahwa metafora terjemahan menjadi cara yang lebih baik untuk memahami apa yang terjadi di dalam arus global ini. ${ }^{19}$

Demikianlah beberapa perspektif teori globalisasi dalam studi media yang nantinya akan dijadikan ukuran dan pertimbangan dalam menganalisis penelitian ini lebih lanjut, terutama untuk menemukan kecenderungan-kecenderungan sebagaimana nantinya akan terlihat dalam beberapa kasus di lapangan.

\section{Bingkai Konseptual}

\section{Menjelaskan rahmatan lil 'alamin.}

Islam adalah agama yang bersifat universal, humanis, dinamis, kontekstual dan akan abadi sepanjang masa. Agama terakhir yang memiliki kitab suci resmi, orisinal dari Allah Swt, dengan rasul terakhir-Nya-penutup para nabi-nabi dan tidak ada nabi setelahnya [Qs. al-Ahzâb/33: 40] Nabi Muhammad Saw. Allah Swt memberikannya al-Qur'an sebagai panduan hidup umatnya yang bersifat universal, sedangkan ucapan, tingkah laku dan diam

17 Gill Branston \& Roy Stafford, The Media Student's Book, 412.

18 Gill Branston \& Roy Stafford, The Media Student's Book, 411.

19 Gill Branston \& Roy Stafford, The Media Student's Book, 410. 
Tantangan Agama di Era Globalisasi: Analisis Strategi Komunikasi, Karakteristik dan Materi Dakwah

Nabi Muhammad Saw umumnya disebut hadis dan sunnah adalah panduan hidup kedua umat Muslim. Islam adalah agama yang menyempurnakan agama-agama sebelumnya. Ibarat bangunan rumah yang kekurangan satu batu bata, agama Islam menyempurnakan ajaranajaran sebelumnya. ${ }^{20}$

Keberagaman yang kokoh adalah fitrah manusia (Qs. al-Rûm/30:30). Pola beragama yang sejuk menjadi fitrah manusia dan meminjam gagasan Karen Armstrong agama yang penuh kasih sayang. ${ }^{21}$ Tetapi petanyaan selanjutnya adalah, mengapa umat Muslim mundur? Amir Sakib Arsilan telah menulis kitab Limadza Taakhkhara al-Muslimûn wa Limâdza Taqaddama Ghairuhum untuk menjawab problem-problem terkait kemunduran Islam dan penghalangnya. Kemunduran umat Muslim, di samping faktor kejumudan berpikir, juga dikarenakan kurang dewasa dalam beragama. ${ }^{22}$

Kedewasaan dalam beragama akan melahirkan perdamaian dan kerukunan lintas kelompok, agama, etnis suku dan ras adalah dambaan Islam. Cita-cita itu tidaklah utopis, kedatangan Islam pun untuk mewarnai kehidupan di bumi, tidak seperti asumsi iblis tatkala Allah Swt ingin menciptakan manusia (Qs. al-Baqarah/2: 30). Namun, tersisa beberapa pertanyaan besar, apakah agama Islam masih relevan di abad teknologi dan sains? Gagasan Islam Rahmatan lil Alamin yang diusung oleh KH. Hasyim Muzadi, menjawab tantangan zaman dengan canggih dan brilian. Gagasan Islam Rahmatan lil Alamin adalah gagasan yang komprehensif dan holistik. Hasyim Muzadi mengungkapkan bahwa dengan Islam Rahmatan lil Alamin mampu membuat para muballighin (penyebar dan pembawa agama) yang membawakan Islam dengan penuh keramahan, kedamaian dan kebijaksanaan, mudah diterima oleh masyarakat dengan sukarela tanpa perlawananan dan kekerasan. ${ }^{23}$

20 Allah tidak saja memberikan panduan hidup_-seperti al-Qur'an untuk umat Nabi Muhammad Sawkepada salah satu agama yang diturunkan-Nya, melainkan wahyu Allah Swt juga pernah diturunkan kepada umatumat sebelumnya oleh nabi-nabi lainnya. Lihat Thomas W. Arnold, Sejarah Da'wah Islam,terj. Nawawi Rambe (Jakarta: Wijaya, t.t.), 27.

21 Karen Armstrong, Compassion: 12 Langkah Menuju Hidup Berbelas Kasih, terj. Yuliani Liputo (Bandung: Mizan, 2012), 67.

22 Amir Sakib Arsilan, Limâdza Taakhkhara al-Muslimûn wa Limâdza Taqaddama Ghairuhum (Beirut: Dâr Maktabah al-Hayât, t.t.), 688.

23 Abdul Muchith Muzadi, Mengenal Nahdlatul Ulama (Surabaya: Khalista, 2006), 1. 
Selanjutnya, arti rahmatan lil alamin dijelaskan adalah memahami al-Qur'an dan Hadis untuk kebaikan semua manusia, alam dan lingkungan. Islam yang dibawa oleh Nabi adalah Islam untuk semua. Islam mengajarkan kasih sayang pada semua makhluk: manusia, binatang, tumbuh-tumbuhan, air, tanah, api, udara dan sebagainya. ${ }^{24}$ Islam memandang bahwa yang memiliki jiwa bukan hanya manusia, tetapi juga tumbuh-tumbuhan dan binatang sehingga mereka itu harus dikasihani. Islam sebagai rahmatan lil alamin ini secara normatif dapat dipahami dari ajaran Islam yang berkaitan dengan akidah, ibadah dan akhlak. Akidah atau keimanan yang dimiliki manusia harus melahirkan tata rabbaniy (sebuah kehidupan yang sesuai dengan aturan Tuhan), tujuan hidup yang mulia, taqwa, tawakkal, ikhlas, ibadah. Aspek akidah ini harus menumbuhkan sikap emansipasi, mengangkat harkat dan martabat manusia, penyadaran masyarakat yang adil, terbuka, demokratis, harmoni dalam pluralisme. ${ }^{25}$ Lebih lanjut, bukti Islam sebagai rahmat bagi seluruh alam adalah dengan diutusnya seorang Rasul dan diturunkannya al-Qur'an yang dapat membantu manusia dalam menjawab berbagai masalah yang tidak dapat dijawab oleh akal pikiran. ${ }^{26}$

Metode KH. Hasyim Muzadi di dalam membawa gagasan Islam Rahmatan lil Alamin dengan menerapkan tiga pola secara proporsional dan seimbang. Pertama, pendekatan dakwah. Penerapan metode ini lebih kepada sisi seorang mursyid (pengayom dan pembimbing), dalam bahasa tasawuf. Mengajak orang yang jelek menjadi baik dan orang yang sudah baik, ditingkatkan kualitasnya. Dalam konteks ini, dalam mengajak orang, tidak hitam-putih. Dicarikan terlebih dahulu illat-nya, kemudian dicarikan obat penyembuhnya, sesuai porsinya.Seorang pendakwah, layaknya apoteker-istilah KH. Hasyim Muzadi, ia harus mengerti dahulu kadar sakit seorang pasien dan diberikan obat sesuai porsi dan frekuensi sakitnya. Seorang pendakwah, harus mengerti kebutuhan masyarakat, tempat berdakwahnya. Kalimat bil-hikmah dalam al-Qur'an mengindikasikan kepada sebuah makna bahwa menjadi pendakwah harus pandai membaca keadaan (mukhatab) dan materi dakwah yang disampaikan bukan sesuai dan ukuran pendakwah. Misalnya, khotib pada ibadah Salat Jum'at. Seorang khotib dalam menyampaikan pesan-pesan ajaran Islam, harus menyesuaikan

24 F.Jabali, dkk. Islam Rahmatan lil alamin (Jakarta: Kementerian Agama; Direktorat Jenderal Pendidikan Islam. Direktorat Pendidikan Agama Islam 2011), 42.

25 N.Madjid,Islam, Doktrin dan Peradaban, (Jakarta:Yayasan Wakaf Paramadina,1992),38.

26 F. Gulen, Islam Rahmatan lil Alamin: Menjawab Pertanyaan dan Kebutuhan Manusia. Jakarta: Republika, 2011),89. 
Tantangan Agama di Era Globalisasi: Analisis Strategi Komunikasi, Karakteristik dan Materi Dakwah

jamaah-nya karena ukuran berhasil seorang khotib ditentukan dari penyesuainnya kepada jamaah dan tingkat pemahaman jamaah atas materi yang disampaikannya.

Adanya periodesasi dakwah yang telah dicontohkan oleh Nabi Muhammad saw ini merupakan pembuktian bahwa kegiatan dakwah harus senantiasa bergerak, dinamis, serta sesuai dengan kondisi masyarakat. Dengan kata lain, dakwah tidak harus berhenti pada satu masa dan tempat yang sama. Selain itu, kedudukan Nabi Muhammad saw sebagai rahmatan lil alamin juga mengharuskan ia untuk berdakwah tidak hanya di Makkah saja, melainkan di tempat lain, termasuk Madinah. Adanya kegiatan dakwah yang sampai ke Madinah tersebut membuktikan bahwa Islam telah meluaskan pengaruhnya, bahkan hingga ke Madinah. Pada dasarnya, pelaksanaan dakwah yang bersifat spesifik, terencana, sistematis, dan strategis yang telah dicontohkan oleh Nabi Muhammad saw merupakan kerangka acuan dakwah yang sebenarnya. Secara historis, para sarjanawan membagi dakwah yang telah dilakukan oleh Nabi Muhammad saw ke dalam dua periode, yaitu periode Makkah yang biasa disebut dengan addaur al-Makki dan periode Madinah yang biasa disebut dengan addaur alMadani. $^{27}$

\section{Menjelaskan ukhuwah basyariyah}

Aktifitas dakwah Nabi Muhammad saw di Madinah terus mengarah kepada perkembangan dakwah yang signifikan serta menampakkan sinyal-sinyal keberhasilan, khususnya pasca penanda tanganan Piagam Madinah. Secara internal, kerukunan umat Islam dan kecintaan mereka terhadap Madinah telah muncul. Akan tetapi terkadang mereka merasakan sikap syu "ubiyah atau fanatik kesukuan itu muncul kembali. Hal tersebut mengisyaratkan bahwa mereka masih memerlukan persaudaraan atas dasar kemanusiaan (ukhuwah basyariah). Karena apabila kondisi ini dibiarkan, maka akan membuka peluang kepada mereka untuk saling mencari kelemahan. ${ }^{28}$

27 Shafiyur Rahman Al-Mubarakfury, Sirah Rasul Saw al-Rahiqul Makhtum, Dar al-Khair, (Beirut Cet. II, 1998), 73 dan J. Suyuthi Pulungan, PrinsipPrinsip Pemerintahan Dalam Piagam Madinah Ditinjau Dari Pandangan al-Qur"ean, ( Jakarta: Rajawali Pers, 1994), 1.

28 Kata Basyariyah yang berakar dari Basyar diulang sebanyak 26 kali dalam AlQuran. Kata ini berarti manusia. Oleh karena itu, penulis mengartikan ukhuwah basyariyah adalah persaudaraan yang dibina atas dasar kemanusiaan.Lihat Al-Baqi, Op.Cit, 153. 
Melihat realita dan perkembangan yang terjadi di kalangan masyarakat Madinah, Nabi Muhammad saw menyusun strategi selanjutnya, yaitu melahirkan sikap kebersamaan. Nabi ingin menanamkan sebuah keyakinan, bahwa semua manusia itu adalah sama. Sama- sama makhluk Allah Swt yang berasal dari satu nenek moyang, yaitu Adam as dan Hawa. Dengan demikian, nabi ingin mengikat mereka dengan tali persudaraan atas dasar nilai kemanusiaan. Sebuah persaudaraan yang diikat atas dasar kesamaan ciptaan, yaitu manusia sebagai ciptaan Allah Swt.

Dalam kajian dakwah, menempatkan manusia pada derajat yang sama merupakan sebuah kemestian. Yang dimaksud "sama" dalam hal ini ialah sama-sama makhluk Allah Swt yang secara fitrah adalah makhluk beragama. Selain itu, manusia juga merupakan makhluk sosial yang mencintai kebersamaan dan membenci pertikaian apalagi permusuhan. Para sosiolog -seumpama Soerjono Soekanto- memang menegaskan bahwa strata kehidupan dalam masyarakat akan menimbulkan rasa persaingan (competition) dan perjuangan untuk bertahan (struggle for exsistence). Keduanya merupakan konsepsi-konsepsi dasar dalam pendekatan ekologis. ${ }^{29}$

Selain sebagai makhluk sosial, manusia juga merupakan makhluk yang berketuhanan. Secara fitrah setiap manusia membutuhkan agama sebagai pengatur hidupnya. Oleh karena itu, Nabi Muhammad saw memfungsikan agama sebagai wadah pemersatu. ia memperlihatkan hubungan yang jelas antara agama dan persamaan derajat. Agama merupakan fasilitator dan dinamisator yang menjembatani perbedaan. Agama juga sangat berperan besar dalam menentukan sisi kehidupan manusia. Ajaran agama merupakan payung besar dalam membingkai kebersamaan. Karena, pada setiap diri manusia ada naluri atau fitrah untuk beragama. Ini adalah modal besar Nabi Muhammad saw dalam mewujudkan ukhuwah basyariah di tengah keragaman masyarakat Madinah. Secara sosiologi, kebutuhan akan agama bersentuhan langsung dengan dinamika masyarakat itu sendiri. Di masyarakat akan terlihat beberapa simbol keagamaan sebagai pengikat. Oleh karena itu, memfungsikan agama sebagai roda persatuan merupakan sesuatu kemestian. ${ }^{30}$

29 Soerjono Soekanto, Beberapa teori Sosiologi Tentang Struktur Masyarakat, (Jakarta: PT. Raja Grafindo, 1993), 69.

30 Hendro Puspito, Sosiologi Agama, (Jakarta: Kanisius , 1992), 38. 
Tantangan Agama di Era Globalisasi: Analisis Strategi Komunikasi, Karakteristik dan Materi Dakwah

Sisi lain dari bentuk ukhuwah basyariah ini, ialah munculnya sebuah realitas kebebasan yang saling menghormati. Jika ukhuwah Islamiyah menumbuhkan kerukunan antar penganut Islam secara internal, maka ukhuwah basyariah menumbuhkan kerukunan antar umat sesama pemeluk agama. Masyarakat Madinah memiliki kebebasan untuk memilih agama yang diyakininya, tetapi harus saling menghormati agama dan kepercayaan orang lain. Dalam pasal 25 Piagam Madinah menyatakan, bahwa orang Yahudi tetap berpegang pada agama mereka begitu pula orang Islam. Fazlur Rahman mengomentari pasal ini sebagai bentuk kebebasan beragama dan berintegrasi sesama manusia sebagai pemeluk agama yang berbeda. $^{31}$

\section{Menjelaskan Al-Muntazhar/Al-Mahdi}

Eskatologi atau ilmu yang mempelajari tentang akhir zaman seperti hari kiamat dan tanda-tandanya, kebangkitan, serta surga dan neraka, merupakan suatu ilmu penting dalam ajaran teologi (akidah), termasuk dalam ajaran agama Islam. Bahkan mempercayai hal ini merupakan salah satu rukun/pilar dari rukun iman yang enam dalam Islam. Salah satu persoalan yang diyakini oleh umat Islam tentang hal ini yaitu akan hadirnya sosok Al-Mahdi pada akhir zaman kelak yang akan menyelematkan umat Islam atas musuh-musuhnya. ${ }^{32}$

Al-Mahdi secara bahasa berarti orang yang diberi petunjuk, sebagaimana yang disebutkan dalam sabda Rasulullah tatkala memberi sifat kepada Khulafa` Rasyidun (Abu Bakar, Umar, Utsman, dan Ali), “Dan sunnah para Khulafa' rasyidin (yang mendapat petunjuk dalam beramal), mahdiyin (yang mendapat petunjuk ilmu)."2 Menurut Ibnul Atsir, arti al-mahdi pada hadits di atas yaitu orang yang Allah beri petunjuk pada kebenaran. ${ }^{33}$ Ia diberi gelar Al-Mahdi karena Allah sendirilah yang memberinya hidayah dan memperbaiki dirinya yang sebelumnya memang seorang manusia biasa. Sebagaimana sabda Rasulullah, "Al-Mahdi berasal dari (keturunan) kami, Ahli Bait. Allah akan memperbaiki (diri)nya dalam satu malam." Bahkan, secara bahasa, Al-Mahdi juga bisa bermakna lebih luas, yaitu siapa saja yang mengikuti jalan hidup mereka dalam beragama. Adapun yang dimaksudkan dengan

31 Fazlur Rahman, Islam, (terj.) Ahsin Muhammad, Mizan, Bandung, 1984, hlm. 13

32 A. Sadikin, Al-Mahdi Khalifah Yang Dibaiat Nabi Isa, (Jakarta: Lembaga Kajian Syamina, 2018 ), 7. 33 Ibnul Atsir, An-Nihayah fi Gharib al-Hadits wa al-Atsar, vol. V, hal. 254. 
Mahdi di sini yaitu Amirul Mukminin dan Khalifah Al-Mahdi yang telah dikabarkan oleh Rasulullah yang kelak akan diutus oleh Allah kepada umat Islam di akhir zaman. Dia akan menguatkan agama ini dan menyebarkan keadilan. Kaum muslimin dan khilafah Islam akan berada di bawah kekuasaannya. ${ }^{34}$

Pembahasan tentang Imam al Mahdi al Muntazhar merupakan pembahasan dogmatis yang berkaitan dengan teologi dan keyakinan. Imam Mahdi diyakini sebagai juru penyelamat adalah sebuah konsep yang sudah diterima oleh semua agama samawi, bahkan oleh semua umat manusia meskipun nama yang ditentukan untuk menyebutnya berbeda-beda.

Tentang keberadaan dan kemunculan Imam Mahdi ini umat Islam menggunakan landasan hadits-hadits nabi SAW. disamping landasan dari beberapa ayat al qur'an yang dianggap terkait dengan masalah Imam Mahd. Salah satu hadits yang biasanya dijadikan landasan adalah hadist riwayat Abu Daud, yang artinya kurang lebih adalah: "Diriwayatkan dari Abu Daud dari Zaidah dari 'Ashim dari Zurr dari Abdullah dari nabi saw bahwa beliau bersabda, "Seandainya tidak tersisa dari (usia) dunia ini kecuali hanya sehari, niscaya Allah akan memanjangkan hari itu hingga Ia membangkitkan seseorang dariku (dari Ahlul baitku) yang namanya sama dengan namaku dan nama ayahnya sama dengan nama ayahku. Ia akan memenuhi bumi ini dengan keadilan sebagaimana ia telah dipenuhi oleh kezaliman dan kelaliman."

Sebagian besar umat Islam mempercayai akan kehadiran Imam di akhir zaman nanti sebagai Ratu Adil. Berdasarkan informasi dari hadits tersebut di atas bahwa Imam Al Mahdi ini berasal dari keluarga Nabi Muhammad Saw. keturunan dari Fatimah RA., bahkan nama Imam Al Mahdi telah disebutkan Nabi Saw. dengan pernyataannya "Namanya adalah namaku dan nama bapaknya adalah nama bapakku".

Kemunculan Al-Mahdi dapat dikatakan sebagai sebuah reformasi (tajdid) besar terhadap tatanan dan nilai dunia pada umumnya, terkhusus dalam internal umat Islam. Pada masa itulah Islam kembali berada di atas puncak peradaban umat manusia. Al-Islam ya'lu wa laa yu'la 'alaih (Islam itu tinggi, dan tidak ada yang lebih tinggi darinya) demikianlah yang digambarkan Rasulullah. Dengan tatanan kekhilafahan yang ia jalankan sehingga ia

34 Lihat Abdul Muhsin Al-'Abbad, 'Aqidah Ahl as-Sunnah wa al-Atsar fi al-Mahdi al-Muntazhar, dalam Majallah al-Jami’ah al-Islamiyyah, vol. I, edisi 3, Februari 1969, hal. 161-162 
mendapat gelar khalifah atau amirul mukminin, sebagaimana yang dikabarkan Rasulullah, pada masanya, dunia akan penuh dengan keadilan, rasa aman, sehingga terwujud kesejahteraan bagi umat manusia. Hari ini, lebih dari satu miliar umat Islam mempercayai dan meyakini kemunculan Al-Mahdi dan menanti kedatangannya pada suatu masa kelak. Ini juga berarti, disadari atau tidak, lebih dari satu miliar umat Islam telah mempercayai hadirnya sistem kekhilafahan Islam yang mendominasi tatanan dunia sekaligus menggantikan tatanan dunia sebelumnya yang terbukti tidak mampu menyejahterakan, memberi keamanan, dan memberi keadilan pada umat manusia.

\section{Tantangan Dakwah di Era Globalisasi}

Ketika masyarakat memasuki era globalisasi dengan dukungan ilmu pengetahuan dan teknologi, tantangan yang dihadapi semakin rumit. Tantangan tersebut tidak mengenal ruang, batas, waktu dan lapisan masyarakat, melainkan ke seluruh sektor kehidupan dan hajat hidup manusia, termasuk agama. Artinya, kehidupan kegamaan umat manusia tidak terkecuali Islam di mana pun ia berada akan menghadapi tantangan yang sama. Soejatmoko menandaskan bahwa agama pun kini sedang diuji dan ditantang oleh zaman. ${ }^{35}$ Meskipun diakui bahwa di satu sisi kemajuan IPTEK menciptakan fasilitas yang memberi peluang bagi pengembangan dakwah, namun antara tantangan dan peluang dakwah dewasa ini, agaknya tidak berimbang. Tantangan dakwah yang amat kompleks dewasa ini dapat dilihat dari minimal dari tiga perspektif, yaitu:

Pertama, perspektif prilaku (behaviouristic perspective). Salah satu tujuan dakwah adalah terjadinya perubahan prilaku (behaviour change) pada masyarakat yang menjadi obyek dakwah kepada situasi yang lebih baik. Tampaknya, sikap dan prilaku (behaviour) masyarakat dewasa ini hampir dapat dipastikan lebih banyak dipengaruhi oleh keadaan sekitarnya.

Kedua, tantangan dakwah dalam perspektif transmisi (transmissional perspective). Dakwah dapat diartikan sebagai proses penyampaian atau transmisi ajaran agama Islam dari

35 Soedjatmoko, 1980, Kesadaran Sejarah dan Pembangunan, Jakarta, Arsip Nasional, 78. 
da'i sebagai sumber kepada mad'u sebagai penerima. Ketika ajaran agama ditrasmisikan kepada masyarakat yang menjadi obyek, maka peranan media sangat menentukan. Ziauddin Sardar mengemukakan bahwa abad informasi ternyata telah menghasilkan sejumlah besar problem. ${ }^{36}$ Menurutnya, bagi dunia Islam, revolusi informasi menghadirkan tantangantantangan khusus yang harus diatasi, agar umat Islam harus bisa memanfaatkannya untuk mencapai tujuan dakwah.

Ketiga, tantangan dakwah perspektif interaksi. Ketika dakwah dilihat sebagai bentuk komunikasi yang khas (komunikasi Islami), maka dengan sendirinya interaksi sosial akan terjadi, dan di dalamnya terbentuk norma-norma tertentu sesuai pesan-pesan dakwah. Yang menjadi tantangan dakwah dewasa ini, adalah bahwa pada saat yang sama masyarakat yang menjadi obyek dakwah pasti berinteraksi dengan pihakpihak lain atau masyarakat sekitarnya yang belum tentu membawa pesan yang baik, bahkan mungkin sebaliknya58. ${ }^{37}$

\section{Subjek dan Objek Penelitian}

Sebelum berbicara lebih jauh lagi tentang karakteristik masyarakat dakwah di era globalisasi informasi saat ini, perlu kita pahami terlebih dahulu dengan baik makna globalisasi informasi beserta dampaknya terhadap perubahan masyarakat yang ada didalamnya. Globalisasi merupakan zaman dimana arus informasi mengalir deras keseluruh penjuru dunia secara simultan tanpa memandang perbedaan suku, ras maupun budaya serta tanpa memperhatikan ruang dan waktu, itulah arus global ketika sudah bergulir diatas dunia ini siapapun tidak ada yang membendung.

Dalam kesempatan ini,yang menjadi subjek peneltian dari peneliti adalah Imam Shamsi Ali. Imam Shamsi Ali adalah Ulama Islam dan Imam terkenal di New York City, Amerika Serikat. Beliau adalah seorang Ulama Tafsir (a revered Qur'an scholar) dan Ilmu Perbandingan Agama, fasih berbicara Indonesia, Inggris, Arab dan Urdu. Saat ini Imam Shamsi Ali menjabat sebagai Direktur/Imam Jamaica Muslim Center New York, komunitas

36 Sardar, Ziauddin, Information and The Muslim World: A Strategy for The Twenty-First Century, diterjemahkan oleh Priyono dengan judul Tantangan Dunia Islam Abad 21 Menjangkau Informasi. Cet. VII, (Bandung: Mizan, 1996) 16-17.

37 Idris, Malik, Strategi Dakwah Kontemporer, Cet. I, (Makassar: Sawah Press, 2007), 111. 
Muslim terbesar di kota New York, Presiden Nusantara Foundation (yayasan yang didirikannya tiga tahun lalu, dan juga Presiden Muslim Foundation of America, sebuah yayasan dakwah di Amerika Serikat.

Imam Shamsi Ali juga pernah menjabat sebagai Imam Islamic Center New York dan Ketua Masjid Al-Hikmah, masjid milik warga Indonesia di kota New York. Kiprahnya di organisasi internasioanl sangat banyak, di antaranya sebagai anggota Dewan Penasehat untuk sejumlah organisasi antara agama, termasuk Pusat Tanenbaum dan Federasi untuk Perdamaian Timur Tengah, Ketua Dewan Pembina untuk Asean Federation of Muslim Amerika Utara, anggota Dewan untuk Kemitraan Imam di NY, pendiri-bersama (co-founder) UNCC (Rohaniwan Universal Koalisi-International). Presiden dan anggota Dewan Yayasan Muslim Amerika, Inc., Ketua Parade tahunan Muslim di NYC., Wakil Presiden Koalisi Asia di Amerika (AAC-USA) dan Perwakilannya di PBB.

Di kalangan komunitas Muslim Indonesia di Amerika Utara Imam Ali adalah Dewan Penasehat IMSA (Indonesian Muslim Society di Amerika), juga Dewan Penasehat ICMI (Indonesian Muslim Society Intelektual di Amerika). Dikenal di kalangan komunitas antar agama, menjadi penceramah di gereja-gereja, sinagog Yahudi, dan lembaga-lembaga lainnya baik secara nasional dan internasional. Imam Shamsi Ali salah satu dari dua Imam yang diundang untuk menemani Presiden George W. Bush di saat mengunjungi Ground Zero beberapa hari setelah 11 September. Berpartisipasi dalam Konferensi Internasional Imam dan Rabi untuk Perdamaian di Seville Spanyol 2006 dan National Summit pertama Imam dan Rabi Amerika Utara 2007, mewakili komunitas Muslim pada diskusi antar-agama dalam acara dialog Agama dan Pembangunan Berkelanjutan di Gedung Putih pada tahun 2007. Imam Ali juga berpartisipasi dalam Dialog Antar Agama Transatlantic 2008 di Frankfurt, Jerman.

Imam Shamsi dinobatkan sebagai salah satu dari tujuh tokoh agama yang paling berpengaruh di New York City oleh New York Magazine (2006). Juga diangkat "Duta Perdamaian" oleh Federasi Internasional Agama Penghargaan Interfaith ICLI 2008. Dan dianugerahi sebagai salah satu dari 100 penerima the 2009 Ellis Island Medal of Honor Award. Ini medali emas bergengsi non militer adalah pengakuan tertinggi yang diberikan kepada imigran dengan kontribusi luar biasa kepada masyarakat Amerika dan dunia dan baginya, 
itu karena dedikasi tanpa henti dalam membangun jembatan antara komunitas agama. Pada tahun 2009, 2010, 2011, 2012, 2013, dan 2014, Imam Ali terpilih sebagai salah satu dari 500 Muslim paling berpengaruh di dunia oleh Studi Islam Royal Center Strategis di Yordania dan Universitas Georgetown.

Riwayat Pendidikan memperoleh gelar BA dalam tafsir dari Universitas Islam Internasional Islamabad-Pakistan pada tahun 1991 dan gelar MA dalam Studi perbandingan Agama dari universitas yang sama pada tahun 1994. Imam Shamsi Ali memiliki kesempatan untuk bertemu dengan berbagai tokoh, seperti mantan Presiden GW Bush, Bill Clinton, Hillary Clinton, Pataki, Michel Bloomberg, serta Presiden Bambang Yudhoyono dan mantan Presiden RI Prof BJ Habibie dan KH Abdurrahman, dan tentunya presiden terpilih Amerika saat ini Donald Trump.

Imam Shamsi Ali telah menerbitkan banyak tulisan di berbagai media, dan beberapa buku antara lain Dai Muda di NYC (GIP, 2008), True Love in America (GIP 2010), Sons of Abraham (Beacon Press, 2013 USA), Menebar Damai di Bumi Barat (Mizan 2014) dan AnakAnak Ibrahim (Mizan 2014), dan 7 Tokoh Dunia (Gramedia 2016). Di penghujung tahun 2014 lalu Imam Shamsi Ali mendirikan Yayasan Nusantara di Amerika untuk menjadi jembatan dakwahnya yang lebih luas, sekaligus menjadi jalan mengenalkan negara asalnya, Indonesia. Kiprahnya di dunia Internasional menjadikannya satu dari segelintir anak bangsa yang "go Internasional" dalam dunia dakwah. Bahkan tidak berlebihan jika dikatakan satu-satunya pemimpin Muslim asal Indonesia yang menembus dunia Barat dalam membangun imej positif tentang agama Islam.

Imam Shamsi Ali yang berasal dari Indonesia, serta lahir dan dibesarkan di Bulukumba, Sulawesi Selatan, daerah yang terkenal perahu kayu tradisional yang disebut pinisi. Berusia 49 tahun dan saat ini tinggal di Jamaika, Queens, dengan Mutiah (istri) dan enam orang anak. Melalui Yayasan Nusantara, Imam Shamsi Ali saat ini sedang berjuang mendirikan pondok pesantren pertama di Amerika. Sebuah properti dengan lahan seluas 7.4 hektar di kota Moodus Connecticut telah dibeli beserta beberapa gedung untuk dijadikan pesantren. Melalui pesantren tersebut Imam Shamsi Ali berusaha mengenalkan Islam yang ramah, berkemajuan dan sejalan dengan nilai-nilai positif modernitas. Atau lebih dikenal dengan istilah Islam yang rahmatan lil-alamin kepada dunia. 


\section{Hasil Analisis}

Untuk mengantisipasi trend masyarakat di era globlisasi para pendakwa harus dapat mempersiapkan materi-materi dakwah yang lebih mengarah pada antisipasi kecenderungankecenderungan masyarakat. Oleh karena itu, maka seluruh komponen dan segenap aspek yang menentukan atas keberhasilan dakwah harus ditata secara professional dan disesuaikan dengan kondisi mad'u agar dapat menghasilkan kemasan dakwah yang benar-benar mampu memperbaiki dan maningkatkan semangat dan kesadaran yang tulus dalam mengaktualisasikan nilai-nilai ajaran Islam.

Ada empat hal penting yang harus diorganisir oleh da'i dalam memfilter trend masyarakat global yang negatif, seiring dengan perkembangan dan trend masyarakat dunia serta masalah manusia yang semakin kompleks, yaitu; ${ }^{38} 1$ ) Perlu adanya konsep dan strategi dakwah yang tepat untuk membentuk ketahanan diri dan keluarga melalui pengefektifan fungsi nilai-nilai agama, karena dengan dasar agama yang kuat dapat dijadikan filter pertama dan utama untuk menghadapi berbagai trend budaya yang tidak sesuai dengan nilai-nilai Islam, 2) Mempertahankan nilai-nilai budaya luhur yang dapat melestarikan tradisi positif yang pada dasarnya tidak bertentangan dengan paham dan ajaran agama (Islam) yang menanamkan nilai-nilai baik dan suci, 3) Perlu dukungan dan keikutsertakan semua lapisan masyarakat untuk menciptakan dan memiliki komitmen yang sama dalam melihat seberapa bergunanya nilai-nilai baru itu untuk sebuah komunitas dan kemajuan masyarakat, dan 4) Kesiapan dan kematangan intelektual serta emosional setiap penerima message baru, apakah hal tersebut memang akan mendatangkan manfaat plus bagi diri dan lingkungannya.

Adapun operasionalisasi dari ketiga metode tersebut dapat dikemukakan sebagai berikut: a) Dakwah bi al-kitabah yaitu berupa buku, majalah, surat, surat kabar, spanduk, pamplet, lukisan-lukisan dan sebagainya, b) Dakwah bi al-lisan, meliputi ceramah, seminar, symposium, diskusi, khutbah, saresehan, brain storming, obrolan, dan sebagainya, dan c)

38 Majid Abdul,Perencanaan Pembelajaran, (Bandung : PT Remaja Rosda karya, 2009), 
Dakwah bi al-hal, yaitu berupa prilaku yang sopan sesuai ajaran Islam, memelihara lingkungan, dan lain sebagainya. ${ }^{39}$

Dalam rangka keberhasilan dakwah di era global, maka diperlukan da'i yang memiliki profil berikut ini, yaitu: memiliki komitmen tauhid, istiqamah dan jujur, memiliki visi yang jelas, memiliki wawasan keislaman, memiliki kemampuan memadukan antara dakwah bi allisan dengan dakwah bi al-hal, sesuai kata dengan perbuatan, berdiri di atas semua paham dan aliran, berpikir strategis, memiliki kemampuan analisis interdisipliner, sanggup berbicara sesuai dengan kemampuan masyarakat. ${ }^{40}$

\section{Kesimpulan}

Dari gambaran tersebut idealnya kita tidak mengambil posisi sebagai pendukung atau penentang globalisasi. Tetapi kita harus menyikapi globalisasi secara kritis, karena kami yakin bahwa kaum muslimin memang harus mengambil sikap kritis dengan menelaah setiap permasalahan yang berkembang dari segala sisinya, bahkan jangan tergesa-gesa mendukung atau menolak arus global tersebut yang datang tanpa disertai kesadaran yang utuh. Ada beberapa hal yang perlu diperhatikan; Pertama, secara praktis pergerakan dakwah dalam teknologi dan media informasi di era globalisasi di dasari oleh Islam rahmatan lil 'alamin. Sekalipun disisi lain dampak proses globalisasi yang terkait dengan kehidupan keagamaan adalah makin menepisnya ruang religiusitas manusia itu sendiri. Kedua, orientasi dalam penyebaran dakwah secara global adalah ukhuwah basyariyah yang selalu membina persaudaraan sesama manusia. Sikap humanisme tanpa memandang latar belakang agama, warna kulit dan ras masyarakat. Ketiga, memiliki pengharapan dalam masa penantian akan hari yang akan datang (Al-Muntazhar). Sebuah prinsip yang memberikan kabar gembira tentang masa depan yang gemilang dan pelaksanaan segenap keadilan sosial bagi seluruh umat manusia.

39 Bachtiar, Wardi. . Metodologi Penelitian Ilmu Dakwah, (Jakarta: logos. Wacana Ilmu, 1997), 34.

40 S Harahap, Metodologi studi dan penelitian ilmu-ilmu ushuluddin, (Yogya: PT. Tiara Wacana Yogya, 1999), 130. 
Bercermin pada kisah sejarah dakwah yang dikembangkan oleh Rasulullah yang sebenarnya juga merupakan gerakan menuju transformasi sosial menuju pada tatanan tranformasi global. Dakwah dijabarkan sebagai gerakan pembebasan dari berbagai bentuk eksploitasi penindasan dan ketidak adilan dalam semua aspek kehidupan. Dari sanalah kemudian terbentuk masyarakat yang memiliki kecanggihan transformasi dan kapasitas politik modern dimasanya.

Untuk itu dalam rangka melahirkan masyarakat humanis dimana masyarakat berperan sebagai subyek dan bukan obyek dibutuhkan munculnya da'i partisipatif yang mampu memfasilitasi masyarakat untuk memahami berbagai masalah, menyatakan pendapat, merencanakan prospek ke depan dan mengevaluasi transformasi global yang kita kehendaki dan akhirnya masyarakat yang menikmati hasilnya. Karakteristik dakwah tersebut ditandai hubungan yang terbuka dan saling menghargai antara da'i dan masyarakat. Isu sentralnya adalah masyarakat dan pengalaman mereka, bukan da'i dan persepsinya. Materi dakwah yang disodorkan dari luar kepada masyarakat untuk diinternalsisakan, dari situlah masyarakat didorong untuk memiliki kesadaran kritis memandang kehidupan seta memperbaiki keadaan.

Untuk menjadikan Islam rahmah li al-'lamin, Nabi Muhammad mengajak umat manusia memeluk dan mengamallkan agama Islam. Dakwah nabi terbentang dalam periode Mekah yang amat getir hingga periode Madinah yang penuh dengan keberhasilan. Dalam pengalaman dakwahnya yang panjang, tampak bahwa nabi mengembangkan dakwah di tengah masyarakat secara bertahap, mulai dari dakwah secara rahasia (sirriyah) dengan pendekatan personal, dakwah terbuka ('alamiyah) dengan pendekatan kolektif, dan dakwah secara politik (siyasah) dengan pendekatan kelembagaan (institusional). Model dakwah pada masa nabi ini perlu dihadirkan kembali nilai dan makna sejarahnya pada masa-masa sesudahnya, lebih-lebih di dunia Islam modern saat ini, tak terkecuali di Indonesia.

\section{Daftar Pustaka}

Agustian, Ari Ginanjar. ESQ; Emotional Spiritual Quetiont. Cet. VI; Jakarta: Arga, 2002. 
Bara Izzat Wiwah Handaru

Al-Hasani, Sayyid Muhammad Alwi Al-Maliki. Kiat Sukses dalam Berdakwah. Jakarta: Amzah, 2006.

Al-Qardhawi, Yusuf. Islam dan Globalisasi Dunia, Jakarta: CV. Pustaka AlKautsar, 2001.

Ali, Mukti. Agama, Moralitas dan Perkembangan Kontemporer dalam, Mukti Ali dkk, Agama dalam Pergaulan Masyarakat Kontemporer, Cet. I; Yogyakarta: Tiara Wacana Yogya, 1998.

Atiyah, Amaluddin, al-Waqi' wa al-mitsāl fi al-fikri al-islami al-mu ' asir, Beirut: Darr al-hudā, 2002.

Aziz, Moh Ali. Dakwah Pemberdayaan Masyarakat: Paradigma Aksi Metodologi. Yogyakarta: Pustaka Pesantren. 2005.

Aziz, Jum `ah Amin Abdul. Fiqih Dakwah. Cet. Ke-4. Solo: Era Intermedia, 2003.

Azizy, Qodri A. Melawan Globalisasi; Reinterpretasi Ajaran Islam. Yogyakarta: Pustaka pelajar, 2004.

Bachtiar, Wardi. Metodologi Penelitian Ilmu Dakwah, Cet. I; Jakarta: Logos Wacana Ilmu, 1997.

Branston, Gill dan Roy Stafford, The Media Student's Book, edisi ketiga. London : Routledge, 2003.

Chinnamai, S. "Effects of Globalization on Education and Culture," in ICDE International Conferenc. New Delhi: ICDE, 2005.

Dermawan, Andi. Ibda' Bi Nafsika; Tafsir Baru Keilmuan Dakwah. Yogyakarta: Tiara Wacana, 2005.

Effendy, Onong Uchjana. Ilmu, Teori dan Filsafat Komunikasi, Cet. II; Bandung: PT. Citra Aditya Bakti, 2000.

Halim, Abdul. El-Muhammady. Dinamika Dakwah Suatu Perspektif dari Zaman Awal Islam hingga Kini, Kuala Lumpur: Budaya Ilmu, 1992.

Harahap, Syahrin. Islam dan Implementasi Pemberdayaan, Cet. I; Yogyakarta: PT. Tiara Wacana Yogyakarta, 1999.

Hoetomo. Kamus Besar Bahasa Indonesia. Surabaya: Mitra Pelajar, 2005. 
Idris, Malik. Strategi Dakwah Kontemporer, Cet. I; Makassar: Sawah Press, 2007.

Jamilah, Maryam. Islam dalam Kancah Modernisasi, Bandung: NV Tarate, 1983.

Katsir, Ibnu. Tafsir Ibnu Katsir. Bogor: Pustaka Imam Syafi'i, 2003.

Kayo, Khatib Pahlawan. Kepemimpinan Islam dan Dakwah. Jakarta: Amzah, 2005.

Madjid, Abd. Tantangan dan Harapan Umat Islam di Era Globalisasi, Cet. I; Bandung: Pustaka Setia, 2000.

Masyhur, Syaikh Musthafa. Fiqh Dakwah Jilid 2. Jakarta: Al-I'tishom Cahaya Umat, 2005.

Mubarok, Achmad. Psikologi Dakwah. Jakarta: Pustaka Firdaus, 2002.

Mulyana, Deddy. Konteks Komunikasi. Bandung: Remaja Rosda Karya, 1996.

Munir, M., dan Wahyu Ilaihi. Manajemen Dakwah. Jakarta: Pranada Media, 2006.

Panuju, Redi. Sistem Komunikasi Indonesia. Yogyakarta: Pustaka Pelajar, 1997.

Pimay, Awaluddin, Metodologi Dakwah, Semarang: Rasail, 2006.

. Paradigma Dakwah Humanis. Semarang: RaSAIL, 2015.

Rais, Amin. Tauhid Sosial. Cet. I; Bandung: Mizan, 1998.

Rantanen, Terhi. Theorizing Media and Globalization. London: SAGE Publications, 2005.

Rianto, P. “Globalisasi Media Dan Transformasi Politik Internasional," Jurnal Ilmu Komunikasi $5,2008$.

Rivers, William L., T. Peterson, dan J.W. Hensen. Media Massa Dan Masyarakat Modern. Jakarta: Kencana, 2014.

Saerozi, Ilmu Dakwah. Yogyakarta: Ombak; anggota IKAPI, 2013.

Saifullah. Dakwah Tekstual Dan Kontesktual. Yogyakarta: AK Group, 2006.

Samantho, Ahmad Y. Jurnalistik Islam. Jakarta: Harakah, 2002.

Samekto, Aji FX. "Mengungkap Relasi Kapitalisme, Demokrasi, Dan Globalisasi: Kajian Dalam Perspektif Studi Hukum Kritis", Jurnal Dinamika Hukum 14, no. 2, 2014. 
Bara Izzat Wiwah Handaru

Saputra, Wahidin. Pengantar Ilmu Dakwah. Jakarta: PT. Rajagrafindo Persada, 2011.

Sardar, Ziauddin. Information and The Muslim World: A Strategy for The Twenty- First Century, diterjemahkan oleh Priyono dengan judul Tantangan Dunia Islam Abad 21 Menjangkau Informasi. Cet. VII,. Bandung: Mizan, 1996.

Soedjatmoko. Kesadaran Sejarah dan Pembangunan, Jakarta, Arsip Nasional, 1980.

Suhartini, $\quad$ B. Perspektif Global. Diakses di internet pada tanggal 24 Juli 2017 dari situs: http://staffnew.uny.ac.id.

Ulumuddin, “Globalisasi Dan Tantangan Dakwah Digital” Jurnal Almanar Edisi 1, Versi pdf, 2004.

Umar, Ratnah. “Metode Dakwah Di Era Globalisasi” Al-Tajdid Vol. I No.2 Maret 2009.

Wahid, Fathul. E-Dakwah: Dakwah Melalui Internet.Yogyakarta: Gava Media, 2004.

Yatim, Badri. Sejarah Peradaban Islam. Jakarta: Raja grafindo Persada, 2008.

Yunus, Mahmud. Kamus Arab-Indonesia. Jakarta: PT. Hidakarya Agung, 1998. 